Article

\title{
Seed Viability of Heracleum mantegazzianum (Apiaceae) Is Quickly Reduced at Temperatures Prevailing in Biogas Plants
}

\author{
Anja Tanke ${ }^{1, *}$, Jürgen Müller ${ }^{2}\left(\right.$ ) and Friederike de Mol ${ }^{1, *}$ \\ 1 Group Crop Health, Faculty of Agricultural and Environmental Sciences, University of Rostock, \\ Satower Straße 48, 18051 Rostock, Germany \\ 2 Group Grassland and Forage Sciences, Faculty of Agricultural and Environmental Sciences, University of \\ Rostock, Justus-von-Liebig-Weg 6, 18059 Rostock, Germany; juergen.mueller3@uni-rostock.de \\ * Correspondence: anja.tanke@uni-rostock.de (A.T.); friederike.de-mol@uni-rostock.de (F.d.M.); \\ Tel.: +49-381-498-3170 (F.d.M.)
}

Received: 29 May 2019; Accepted: 19 June 2019; Published: 21 June 2019

\begin{abstract}
Heracleum mantegazzianum is an invasive plant species with enormous effect on ecosystems and human health. Mechanical weed management often results in large amounts of biomass. Fermentation in biogas plants can be used for disposal of this biomass contaminated with seeds and for energetic utilization, if spreading of viable seeds with fermentation residues is prevented. Our aim is to quantify the risk of seed survival in mesophilic biogas plants. Seeds were harvested at three ripening stages in central Germany. They were incubated for $0,0.5,1,2,4$, and 8 days at 35 and $42{ }^{\circ} \mathrm{C}$ in water baths. Thereafter, seed viability was assessed by a tetrazolium test. Furthermore, germinative capacity of seeds which had passed an incubation of $48 \mathrm{~h}$ at $35^{\circ} \mathrm{C}$ were tested. After eight days in water bath none of the 1199 tested seeds were viable anymore. The time until half of the seeds died $\left(\mathrm{ED}_{50}\right)$ ranged from 9 to $65 \mathrm{~h}$, whereby high temperature accelerated the mortality. Germinative capacity was similar to the seed survival rate. The results suggest that fermentation of H. mantegazzianum biomass poses only a low risk of viable seed spread, if the operating temperature of the biogas plant achieves $42{ }^{\circ} \mathrm{C}$ and a high retention time is ensured.
\end{abstract}

Keywords: giant hogweed; biogas reactor; biomass disposal; germinative capacity; invasive plant management; water bath

\section{Introduction}

Heracleum mantegazzianum Sommier \& Levier, giant hogweed, is one of the most successful invader weed species in Europe [1], causing biodiversity loss and reduced ecosystem functioning [2-4]. Due to its rapid, competitive growth and reproduction potential giant hogweed species have a high potential for further infestation and strong survival [5-7]. Preserving biodiversity is part of the Convention on Biodiversity, particularly with regard to taking precautions against alien species and, if necessary, controlling them [8]. In the vicinity of human settlements, control of $H$. mantegazzianum is necessary due to health hazards, because it contains photosensitive furanocoumarins that can cause skin burns and blindness [9]. In a large spatial landscape context, long-term strategic approaches are required to repress the invasion [10]. At a local scale, management tools for H. mantegazzianum, in particular cutting, result in a huge amount of biomass [11]. Contamination of the biomass with germinable seeds poses a risk of dispersal during disposal and promotes further infestation.

The native distribution area of the herbaceous umbellifer $H$. mantegazzianum is the western Caucasus [12,13]. After being introduced as a garden ornamental in Europe from the 1800s, it spread quickly [14-18]. The use as a pollen and nectar supplying plant [19] and to a lesser extent as material 
for silage in the twentieth century has led to further distribution [16]. Today, it is widespread across temperate Europe and has also invaded North America and Australia [14,20]. In the research area of our study, central Europe, this perennial plant germinates early in the year from January to March [21]. It grows rapidly up to $5 \mathrm{~m}$ high [14], forming stands where it dominates other vegetation. Usually, flowering and seed production start in the third year of growth, when sufficient reserves are stored in the roots [22]. Once accomplished, flowering begins at the end of June up to the beginning of July [23] and ripening of the seeds begins in the second half of July [24]. Heracleum mantegazzianum is monocarpic and dies after flowering [24]. It is exclusively seed-propagated. On average, the plant produces 10,000 to 20,000 flat, elliptical seeds (Figure 1) [22,23]. The seed bank type is classified as short-term persistent [21]. In the first year, the survival rate in the seed bank was found to range about $9 \%$ [25]. After five years, the seed bank survival never exceeded 1\% [26]. The seeds contain an underdeveloped embryo and are morpho-physiological dormant [21]. Before germination, the seeds need to be stratified by cold and wet conditions during winter [22]. Seed dispersal vectors are mainly water, wind, wildlife, and human activities [21]. The seeds are able to float for three days and spread quickly along rivers [27]. When growing along the riverside, it promotes the erosion potential of river banks [17]. Other common habitats are margins of woodlands and grasslands [1], ruderal places, and rubbish dumps [28].

Depending on the location, H. mantegazzianum can be controlled by manual and mechanical measures (cutting, ploughing), grazing [29], or with herbicides [29-31]. Cutting the root or the whole plant takes advantage of nutrient depletion in order to prevent accumulation of energy for flowering and reproduction. Early and repeatedly done, it is an effective but labor-intensive method. Umbel removal terminates the monocarpic lifecycle and is effective but risky if ripe seeds shed early. All actions have to be executed until the seed bank is empty and the root system is dead [1].

The treatment of the resulting biomass is crucial for most of the control measures. In tests, H. mantegazzianum was suited as feedstock for biogas production, similar to current agricultural crops [32]. Using biogas plants for disposal of the accrued biomass can generate an additional use and reduce costs. However, the introduction of a large number of seeds into the biogas plant is risky: a new seed dispersal pathway via fermentation residues must be prevented.

During the anaerobic biogas process, seeds are affected by $\mathrm{pH}$ value (6.8 to 8$)$, by the operating temperature ( 20 to $40{ }^{\circ} \mathrm{C}$ in mesophilic fermenters), and by microorganisms and chemicals like enzymes and acids [33]. High temperatures and a long exposure time to such high temperatures are regarded as main factors for inactivation of seeds $[33,34]$. The time until half of the formerly viable seeds are inactivated varies between hours and weeks depending on the species [35]. After 40 days in a mesophilic digester at $37^{\circ} \mathrm{C}$, all $\mathrm{H}$. mantegazzianum seeds had died [32]. However, a batch system does not correspond to conditions in usually used continuous flow-through biogas plants. The average retention time varies between 20 and 40 days in such systems [33], but one percent of the material leaves the biogas plant after just one day [36]. Apart from external factors, survival of seeds is influenced by the seed characteristics (e.g., traits of the seeds, like hard seed coats) and metabolic (in)activity of the embryo, like the dormancy state. Seed resistance against conditions prevailing in biogas plants may; therefore, depend on the maturity of the seeds. From the perspective of invasive weed management; therefore, it is important to determine the right time for plant cutting.

In this study, H. mantegazzianum seeds were sampled in central Germany at different ripening stages. Laboratory water baths at different temperatures were used for seed incubation. This incubation method has been proven to be a good proxy for conditions common in biogas plants [37]. Because microorganisms, acids, and enzymes are missing in water baths, seed survival will be overestimated rather than underestimated, which is reasonable in the context of risk assessment. Seed viability was tested after different exposure times to determine the rate of inactivation. Additionally, germination tests were run to assess the performance of incubated seeds if released in the environment.

The overall objective of our study was to assess the risk of distributing viable H. mantegazzianum seeds with fermentation residues. We hypothesized that: 
i. Seed survival will increase when the incubation temperature decreases,

ii. Seed survival will increase when seeds are more mature,

iii. Viable seeds will germinate after stratification, independently from previous incubation.

Based on the results, we suggested management principles using biogas plants for H. mantegazzianum biomass disposal in order to prevent further spread, to facilitate the eradication efforts and to generate an additional biomass use.

\section{Materials and Methods}

\subsection{Seed Sampling}

Heracleum mantegazzianum seeds were collected in Meiningen, Germany (50 32'36.9" N $\left.10^{\circ} 23^{\prime} 54.2^{\prime \prime} \mathrm{E}\right)$, from July to August 2018. On 1 July 2018, two weeks after the begin of flowering of the main umbel, transparent perforated and air-permeable polyethylene bags (Crispac Bag, $330 \times 500 \mathrm{~mm}$, pores $2 \mathrm{~mm}$ ) were put over the terminal flower to avoid seed losses (Figure A1). Some umbels were trimmed beforehand to fit into the bags. At the time of bagging, all bagged flowers had already set seeds. Seeds were harvested at three different times: two (early), five (intermediate), and eight (late) weeks after flowering begin. Harvested seeds were air-dried at room temperature and kept dark until the beginning of the experiment.

\subsection{Seed Survival in Water Baths}

Seed survival of five individual plants per harvest time was tested in water baths at 35 and $42{ }^{\circ} \mathrm{C}$, corresponding to often prevailing operating temperatures in mesophilic digesters (accuracy: $0.1{ }^{\circ} \mathrm{C}$; WB-6, witeg Labortechnik GmbH, Wertheim, Germany). Twenty-four hours prior to the experiment the seeds swelled in containers with water-saturated air to increase the metabolic activity of all seeds, both untreated and later treated. Then the seeds were surface sterilized with $1 \% \mathrm{NaOCl}$ for two minutes and washed three times with distilled water under sterile conditions. Tubes were filled with 20 seeds each and $7 \mathrm{~mL} 0.5$ M HEPES buffer (pH 7.0) was added. Seeds were incubated 0, 0.5, 1, 2, 4, and 8 days, respectively. For each temperature and incubation period, two replicates per individual were tested. After incubation, the viability of the seeds was determined by tetrazolium chloride staining (TTC) [38]. The seeds were pricked and incubated with $1 \%$ TTC solution at $35^{\circ} \mathrm{C}$ for $24 \mathrm{~h}$. Finally, the seeds were cut, and the color of the embryos was evaluated (Figure 1). Embryos were considered as viable if they had a red staining. Embryos were classified pink if radicle or cotyledon were not stained or if the whole embryo was light pink stained. We considered embryos with pink staining as "damaged". White embryos without any staining were considered as dead. Within the last category "rotten," the embryo structures were no longer detectable.

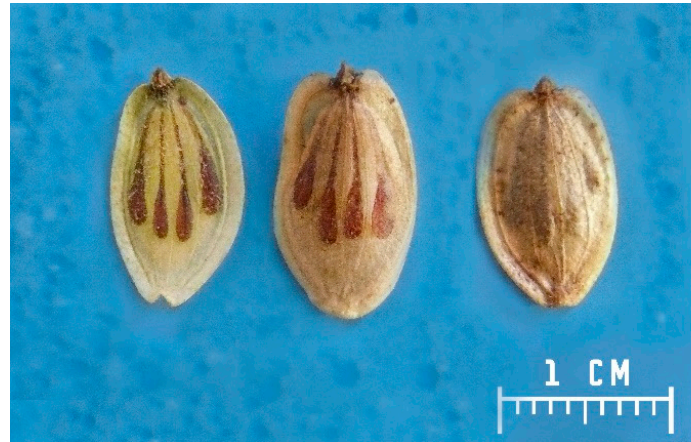

(A)

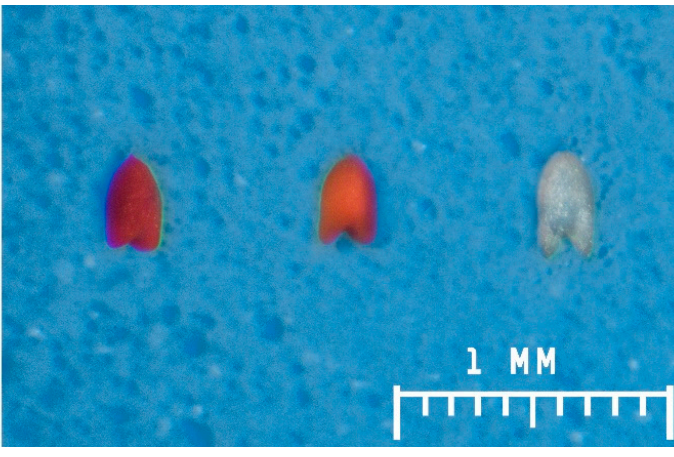

(B)

Figure 1. (A): Heracleum mantegazzianum seeds, harvested 2 weeks (early), 5 weeks (intermediate), 8 weeks (late) after flowering. (B): Embryos stained with tetrazolium chloride for different viability categories: viable (red), damaged (pink), dead (white). 


\subsection{Germination after Stratification}

Seeds were treated as in the seed viability test and incubated for $48 \mathrm{~h}$ at $35^{\circ} \mathrm{C}$ in the water bath. Three individuals of each harvest group were tested with twelve replicates of 25 seeds ( 900 seeds per harvest group in total), except intermediate (three individuals and one mixture of different individuals with nine replicates), in total 2700 seeds. The 2700 untreated seeds (control treatment) were only surface-sterilized and washed with distilled water. Each 25 seeds were sown in $5 \times 5 \mathrm{~cm}$ pots and covered with $0.5 \mathrm{~cm}$ soil. The soil was a mixture of loamy sandy soil and potting soil with peat as a main component. The pots were buried completely randomized surface flush for a 60-day-stratification in the field of the experimental station of Rostock University $\left(54^{\circ} 04^{\prime} 04.1^{\prime \prime} \mathrm{N}\right.$ $12^{\circ} 04^{\prime} 55.7^{\prime \prime}$ E). During stratification between 21 December 2018 and 15 February 2019, precipitation was $100.9 \mathrm{~mm}$, the mean temperature was $1.9^{\circ} \mathrm{C}(20 \mathrm{~cm}$ above ground), and there were 27 frost nights (data from Institute for Water Management, University of Rostock). From 15 February 2019 to 01 April 2019 pots were exposed to $12 \mathrm{~h}$ day/12 h night intervals at 20 and $5{ }^{\circ} \mathrm{C}$, respectively, in a climate chamber (Type KBWF-720, Binder GmbH, Tuttlingen, Germany) in a completely randomized design. Seedlings were counted and removed from the pots weekly.

\subsection{Statistical Evaluation}

For each temperature, at all harvest times, time-response curves were fitted simultaneously using the "drc" package (version 3.0-1) [39] provided in R (version 3.5.0) [40]. Separate models were fitted for viable embryos (red stained) and pooled viable and damaged embryos (red and pink stained). Parameters were estimated for the four-parameter log-logistic model [41]:

$$
f(x,(b, c, d, e))=c+\frac{d-c}{(1+\exp (b(\log (x)-\log (e))))}
$$

where $f$ is the response proportion of viable and damaged embryos depending on incubation time $x, c$ and $d$ are the lower and upper limits of the response, $b$ is the steepness of the curve, and $e$ is the effective time $\mathrm{ED}_{50}$, the time until half of former viable seeds are affected. $\mathrm{ED}_{50}$ values were compared with $t$-tests, and differences were considered as significant if the $p$-value was $<0.05$.

For the statistical analysis of the germination test, the factors treatment (untreated vs. incubated) and maturity stage of the seeds (early, intermediate, late) were combined to six independent variables. The effect of these variables on the germination rate was analyzed with a general linear model with binomial distribution and a logit link function. Pairwise comparisons as implemented in the R package "multcomp" [42] were used to test the hypotheses that there was no difference in germination rates between untreated and incubated seeds within single maturity groups, and additionally that there was no difference between maturity groups within the two treatments.

\section{Results}

\subsection{Seed Viability after Incubation}

After eight days in a water bath, no viable (red stained) embryos from 1199 tested seeds were left at any temperature or harvest (Table 1). At $35^{\circ} \mathrm{C}$, only $1 \%$ survived the four-day incubation. Already after two days at $42{ }^{\circ} \mathrm{C}$ no embryos were viable anymore. At both temperatures within the intermediate and late harvested seeds there were damaged (pink stained) embryos at every time. In particular, there were still three damaged embryos after eight days at $42^{\circ} \mathrm{C}$ in intermediate and late harvest, while in early harvested seeds at $42^{\circ} \mathrm{C}$ there were no more viable or damaged embryos after two days. 
Table 1. Number of embryos for each staining, harvest, duration in water bath, and temperature after tetrazolium chloride staining (TTC) solution testing.

\begin{tabular}{|c|c|c|c|c|c|c|c|c|c|c|c|c|c|c|c|c|c|c|c|c|}
\hline \multirow{2}{*}{\multicolumn{2}{|c|}{ Untreated }} & \multicolumn{5}{|c|}{ Early } & \multirow{2}{*}{\multicolumn{2}{|c|}{ Untreated }} & \multicolumn{5}{|c|}{ Intermediate } & \multirow{2}{*}{\multicolumn{2}{|c|}{ Untreated }} & \multicolumn{5}{|c|}{ Late } \\
\hline & & $\begin{array}{r}\text { Red } \\
204\end{array}$ & $\begin{array}{c}\text { Pink } \\
120\end{array}$ & $\begin{array}{c}\text { White } \\
13\end{array}$ & $\begin{array}{c}\text { Rotten } \\
63\end{array}$ & $\begin{array}{c}n \\
400\end{array}$ & & & $\begin{array}{c}\text { Red } \\
47\end{array}$ & $\begin{array}{c}\text { Pink } \\
112\end{array}$ & $\begin{array}{c}\text { White } \\
74\end{array}$ & $\begin{array}{c}\text { Rotten } \\
167\end{array}$ & $\begin{array}{c}n \\
400\end{array}$ & & & $\begin{array}{c}\text { Red } \\
29\end{array}$ & $\begin{array}{c}\text { Pink } \\
97\end{array}$ & $\begin{array}{c}\text { White } \\
64\end{array}$ & $\begin{array}{c}\text { Rotten } \\
210\end{array}$ & $\begin{array}{c}n \\
400\end{array}$ \\
\hline \multirow[t]{2}{*}{$12 \mathrm{~h}$} & $35^{\circ} \mathrm{C}$ & 122 & 47 & 2 & 28 & 199 & $12 \mathrm{~h}$ & $35^{\circ} \mathrm{C}$ & 25 & 59 & 29 & 87 & 200 & $12 \mathrm{~h}$ & $35^{\circ} \mathrm{C}$ & 5 & 60 & 28 & 107 & 200 \\
\hline & $42{ }^{\circ} \mathrm{C}$ & 25 & 83 & 57 & 35 & 200 & & $42^{\circ} \mathrm{C}$ & 9 & 45 & 59 & 88 & 201 & & $42^{\circ} \mathrm{C}$ & 10 & 33 & 54 & 103 & 200 \\
\hline \multirow[t]{2}{*}{$1 \mathrm{~d}$} & $35^{\circ} \mathrm{C}$ & 87 & 64 & 12 & 37 & 200 & $1 \mathrm{~d}$ & $35^{\circ} \mathrm{C}$ & 21 & 55 & 29 & 95 & 200 & $1 \mathrm{~d}$ & $35^{\circ} \mathrm{C}$ & 6 & 47 & 25 & 122 & 200 \\
\hline & $42^{\circ} \mathrm{C}$ & 1 & 19 & 141 & 40 & 201 & & $42{ }^{\circ} \mathrm{C}$ & 3 & 22 & 71 & 103 & 199 & & $42{ }^{\circ} \mathrm{C}$ & 4 & 12 & 72 & 110 & 198 \\
\hline \multirow[t]{2}{*}{$2 \mathrm{~d}$} & $35^{\circ} \mathrm{C}$ & 20 & 45 & 94 & 41 & 200 & $2 \mathrm{~d}$ & $35^{\circ} \mathrm{C}$ & 14 & 38 & 38 & 110 & 200 & $2 \mathrm{~d}$ & $35^{\circ} \mathrm{C}$ & 8 & 22 & 57 & 114 & 201 \\
\hline & $42{ }^{\circ} \mathrm{C}$ & 0 & 0 & 158 & 42 & 200 & & $42{ }^{\circ} \mathrm{C}$ & 0 & 3 & 91 & 106 & 200 & & $42^{\circ} \mathrm{C}$ & 0 & 1 & 98 & 101 & 200 \\
\hline \multirow[t]{2}{*}{$4 \mathrm{~d}$} & $35^{\circ} \mathrm{C}$ & 2 & 12 & 153 & 33 & 200 & $4 \mathrm{~d}$ & $35^{\circ} \mathrm{C}$ & 4 & 8 & 84 & 104 & 200 & $4 \mathrm{~d}$ & $35^{\circ} \mathrm{C}$ & 0 & 4 & 86 & 110 & 200 \\
\hline & $42^{\circ} \mathrm{C}$ & 0 & 0 & 163 & 37 & 200 & & $42{ }^{\circ} \mathrm{C}$ & 0 & 2 & 101 & 98 & 201 & & $42^{\circ} \mathrm{C}$ & 0 & 4 & 73 & 123 & 200 \\
\hline \multirow[t]{2}{*}{$8 \mathrm{~d}$} & $35^{\circ} \mathrm{C}$ & 0 & 0 & 164 & 36 & 200 & $8 \mathrm{~d}$ & $35^{\circ} \mathrm{C}$ & 0 & 1 & 90 & 109 & 200 & $8 \mathrm{~d}$ & $35^{\circ} \mathrm{C}$ & 0 & 2 & 83 & 114 & 199 \\
\hline & $42{ }^{\circ} \mathrm{C}$ & 0 & 0 & 161 & 39 & 200 & & $42{ }^{\circ} \mathrm{C}$ & 0 & 3 & 87 & 110 & 200 & & $42{ }^{\circ} \mathrm{C}$ & 0 & 3 & 74 & 123 & 200 \\
\hline
\end{tabular}


The viability declined within the $192 \mathrm{~h}$ period and approached zero (Figure 2) at both temperatures but more rapidly at $42{ }^{\circ} \mathrm{C}$. The later the seeds were harvested, the less viable they were at the start of the experiment (Table 1, Figure 2). The proportion of rotten seeds in the intermediate and late harvest was much higher than in the early harvest. Late harvested seeds contained more than half rotten embryos (Table 1). Generally, the log-logistic model fitted counted values well (Figure 2). However, the proportion of viable embryos increased after $12 \mathrm{~h}$, which cannot be fitted by the log-logistic model.
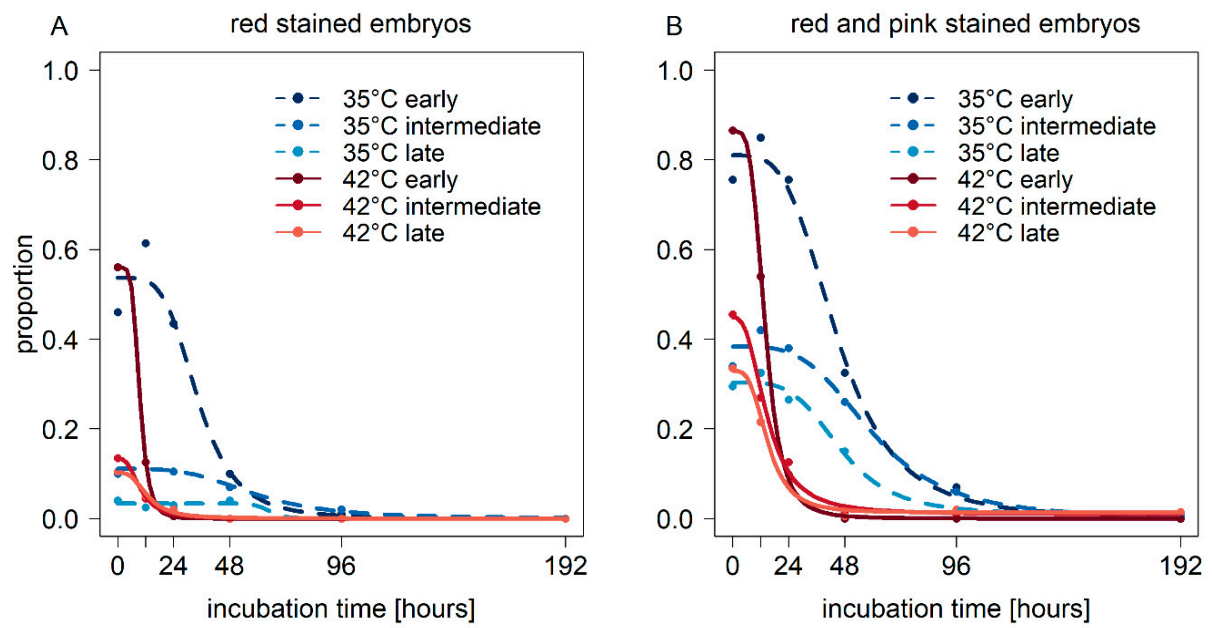

Figure 2. Survival probability of Heracleum mantegazzianum seeds as a function of proportion of stained seeds depending on incubation time to water bath at 35 and $42{ }^{\circ} \mathrm{C}$, for harvest times: 2 weeks (early), 5 weeks (intermediate), and 8 weeks (late) after flowering. Survival probability for: (A) Red stained embryos, (B) Pink and red stained embryos.

After 9 to $12 \mathrm{~h}$ at $42{ }^{\circ} \mathrm{C}$, half of the fully viable embryos were negatively affected (Figure 3A). After around $14 \mathrm{~h}$, half of the embryos were dead (Figure $3 \mathrm{~B}$ ). At $35^{\circ} \mathrm{C}$, half of the viable seeds were eliminated after $34 \mathrm{~h}$ (early), $58 \mathrm{~h}$ (intermediate), and $65 \mathrm{~h}$ (late). The $\mathrm{ED}_{50}$ value for all seeds (viable and damaged) was reached after 44,59 , and $46 \mathrm{~h}$, respectively. The differences between the two temperatures were highly significant $\left(p<0.01\right.$, $t$-test). There were significant differences at $35^{\circ} \mathrm{C}$ between early and intermediate harvest ( $p<0.001$ viable (red), $t$-test; $p<0.003$ viable and damaged (pink and red), $t$-test), while the influence of temperature at $42{ }^{\circ} \mathrm{C}$ was independent of the time of harvest.
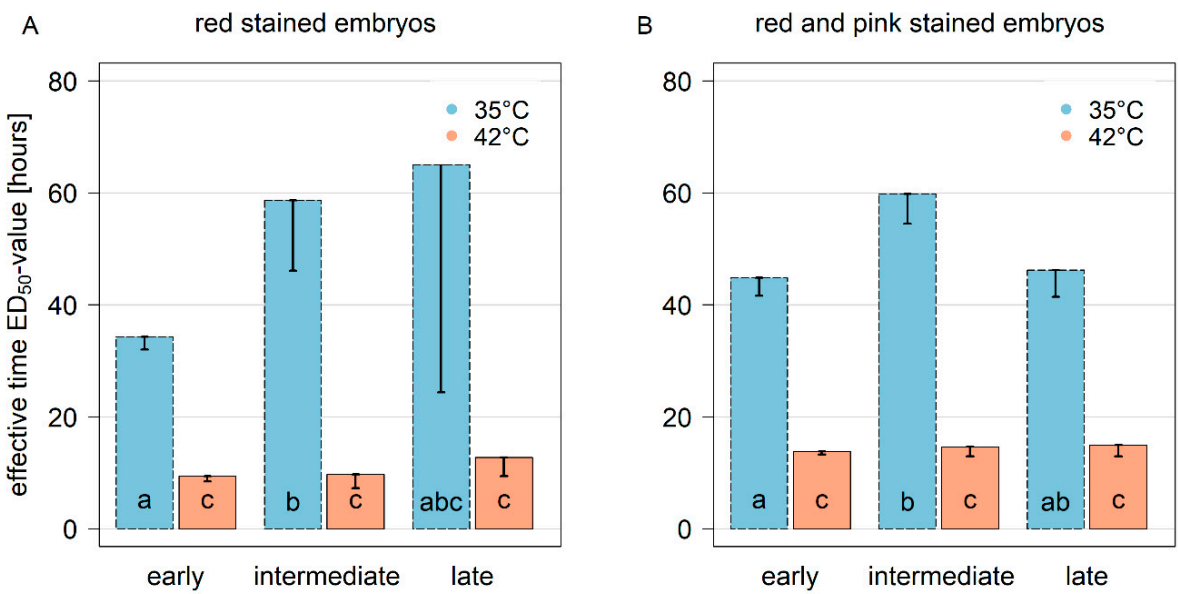

Figure 3. $\mathrm{ED}_{50}$ values, the time until half of former viable seeds are negatively affected, of Heracleum mantegazzianum seeds in hours of exposure time in water baths at 35 and $42{ }^{\circ} \mathrm{C}$, for harvest times: 2 weeks (early), 5 weeks (intermediate), and 8 weeks (late) after flowering. (A) Viable (red) embryos; (B) Viable (red) and damaged (pink) embryos. Mean and lower part of the symmetrical standard error. Letters show significant differences between treatments $(p<0.05$, non-parametric posthoc test). 


\subsection{Germination after Stratification}

The first seedlings germinated two weeks after exposing them to conditions in the climate chamber. Across all harvest times, $14.2 \%$ of the untreated and $0.8 \%$ of the incubated seeds germinated. These numbers correspond to $23.3 \%$ and $7.0 \%$ viable seeds, calculated from the viability tests (Table 1 ). Significant differences $(p<0.001)$ were found between germination rates of incubated and untreated seeds within the same maturity stage. While different maturity stages of untreated seeds revealed significantly different germination rates $(p<0.001)$, no such effect could be detected between maturity stages of incubated seeds $(p>0.05)$. There was a tendency that a higher rate of mature seeds than of premature seeds germinated after incubation, while a higher rate of early harvested seeds germinated, if they were not incubated (Figure 4.)

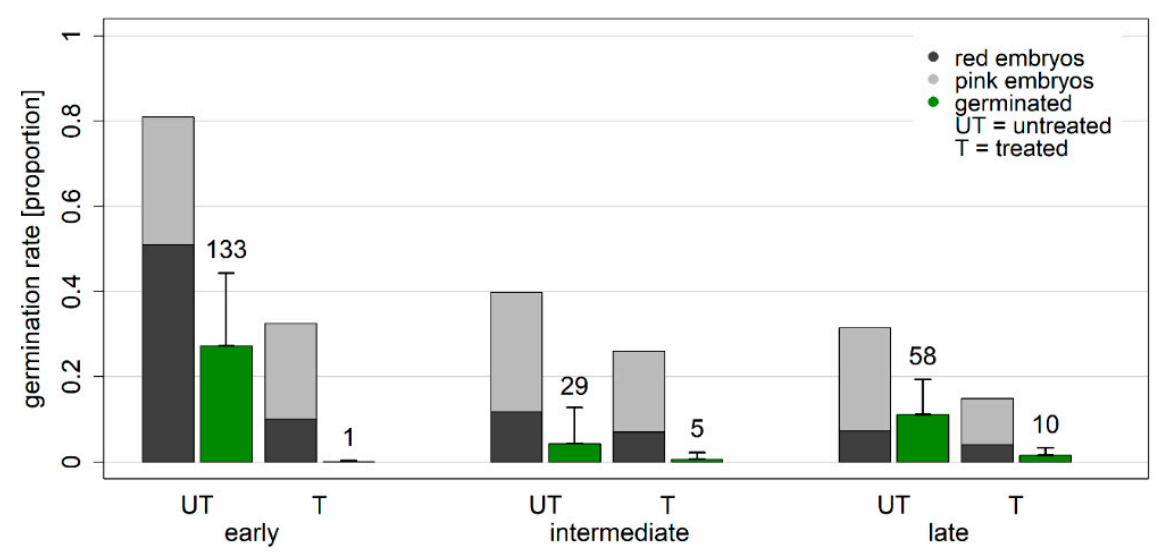

Figure 4. Comparison between actual and potential germination rate of Heracleum mantegazzianum seeds. Germination rate for different harvest times ( 2 weeks (early), 5 weeks (intermediate), 8 weeks (late) after flowering) and treatments (UT: Untreated; T: Incubated in $35{ }^{\circ} \mathrm{C}$ water bath for $48 \mathrm{~h}$ ). Mean number of germinated seeds (green bars, $n=900$ seeds per harvest time and treatment) and maximum number (whiskers and numbers, $n=300$ seeds per individual). Potential germination rate calculated from viable (red) and damaged (pink) embryos (grey bars, values of water bath tests for survival after $48 \mathrm{~h}$ at $35^{\circ} \mathrm{C}$, Table 1, UT: $n=400$, T: $\left.n=200\right)$.

\section{Discussion}

To our knowledge, this is the first study dealing with the problem of Heracleum mantegazzianum seed survival under conditions common in biogas fermenters. Taking into account that most seeds lose their viability faster under anaerobic digestion conditions, than under hot water bath conditions only [37], biogas plants seem to be a possible disposal method for biomass resulting from control measures.

A nonlinear decline of seed viability and germination capacity has been reported for seeds which passed biogas plants under anaerobic digestion conditions [43-50] and for seeds that have been exposed to different temperatures in water baths [34]. After eight-day incubation in hot water no viable seeds occurred. It is known that seed morphology influences the survival of seeds under moist and warm conditions [43]. Hard coated seeds that have a water impermeable layer are more thermoresistant and are inactivated slower. Chenopodium album $\mathrm{L}$. seeds for example are hard coated and cannot be fermented at all [35], whereas H. mantegazzianum can be classified into the group of species without hard shelled seeds and a quick inactivation rate. With only $14 \mathrm{~h}$ under hot water conditions, the effective time until half of the seeds are dead is short compared to other members of the Apiaceae family. Seeds of Daucus carota L., a well-known representative of the Apiaceae, remain alive for about $29 \mathrm{~h}$ at $42{ }^{\circ} \mathrm{C}$ [43]. Generally, different temperatures affected seed survival more than harvest time in this study. We confirm our hypothesis (i) that the mortality process accelerated with increasing temperature. Other studies have shown that a rapid decrease in vitality is connected with increasing temperature $[34,51]$. The range of operating temperatures in mesophilic biogas plants is probably the same range which is needed to inactivate many species [44]. Even though the effect of seed inactivation 
was stronger at $42{ }^{\circ} \mathrm{C}$, seeds of $H$. mantegazzianum were inactivated at low mesophilic temperatures, if they were exposed to such an environment for a longer time.

While there were no differences at $42{ }^{\circ} \mathrm{C}$, the effect of the harvest time becomes evident at $35^{\circ} \mathrm{C}$. The seeds harvested later turned out to be more resistant to heat. This may be caused by reduced thermosensitivity that evolves during the ripening process [52]. The differences between the cutting options in time reveal a conflict in the management. On the one hand, an early harvest reduces the inactivation time in comparison to later harvested seeds, and it avoids mature seeds falling out of the flower head during later harvest. On the other hand, the high regeneration potential is problematic, because early cut plants might regenerate and flower again.

The seed viability at the beginning of the experiments and the germination rates were low, especially for the late harvest. During germination tests barely $14.2 \%$ of the untreated seeds germinated, although germination rates up to $90 \%$ had been reported for $H$. mantegazzianum by Moravcová et al. [53]. The initial seed viability decreased from harvest to harvest. Since some samples from the late harvest were visibly infested by fungi, we assume that the bags had a heat and moisture accumulating effect that promoted fungal growth. This probably promoted the reduction of vitality. This aspect should be explored in further studies. Seed viability could also have suffered from air-drying, although pronounced dry periods are characteristic in the study area at the time of seed ripening too.

Under appropriate germination conditions, a red-stained embryo should sprout a seedling. At the end of the experiment, no red seed occurred. However, pink-stained embryos were present at both temperatures after the eight days at the end of the experiment. During the TTC test, an embryo can be classified as pink for two reasons. Either the embryo has less metabolic activity or some parts of the embryo, such as radicle or cotyledon, are not stained due to lack of activity. If the former is the case, it is possible that a seedling may develop with a time delay in contrast to the other seeds. During standardized germination tests with a limited observation period this could not be confirmed. Consequently, we interpret this as supporting evidence for the assumption that damaged seeds are not able to survive a water bath treatment and following stratification with low temperatures. But as the number of seedlings in untreated late seeds exceeded the number of red-stained embryos, there is a need for further research to investigate the behavior of pink seeds.

The four-parametric log-logistic function fitted the data well, but underestimated the number of viable seeds at $12 \mathrm{~h}$ across all samples. The phenomenon that viability increases above the initial viability value has been reported before. An increase up to $105 \%$ of vital seeds in Echinochloa crus-galli (L.) P. BEAUV. was observed in water bath tests by Oechsner et al. [54]. A reason for this might be that dried seeds, even if they were exposed to water saturated air, need more time to absorb moisture for full metabolic activity.

General specific knowledge about detailed influences on seed survival is missing [33]. In our experiment we were able to show the importance of high temperatures in decreasing seed viability, similar to what has been observed in many studies on other species. So far, the focus has been on weeds in crops. Further research could focus on other invasive plants that are important in landscape conversation and; furthermore, test their potential for disposal in biogas plants. In this way a cheap disposal opportunity could be created as well as an additional use from management of invasive species in the production of gas, energy, and safe fertilizers.

\section{Conclusions}

For the invasive species management, our results suggest that the disposal of $H$. mantegazzianum biomass contaminated with seeds in biogas plants poses only a low risk. Nevertheless, the risk is a function of the number of viable seeds introduced in the biogas process. These, in turn, depend on the amount of biomass, the number of seeds per plant, and the viability of seeds. In any case, the fermentation technology should be appropriate: The fermentation process should run at a high mesophilic, up to thermophilic, temperature range to ensure that no viable seeds survive. If the biogas 
plant cannot be set at a constant high temperature, the biomass should stay longer in the biogas plant. With an average residence time of 20 to 40 days in a flow-through biogas plant, the risk of spreading the seeds through the fermentation residues is largely reduced. Material that has only been in the biogas plant for a short time should be post-treated to ensure a total reduction in viability. Earlier harvest times facilitate seed inactivation. If resources, personal and financial, are restricted to only one measure, this measure should take place at an intermediate maturity stage as a compromise, balancing the benefit of greater inactivation in early cuttings with the danger of seed shattering for delayed cuttings. Nevertheless, it is possible to dispose of later harvested seeds. The consideration of these safety aspects is indispensable because just a few viable seeds would be able to develop a new population.

Author Contributions: Conceptualization, F.d.M. and J.M.; methodology, F.d.M.; validation, A.T., J.M., and F.d.M.; formal analysis, A.T.; investigation, A.T.; resources, University of Rostock, Crop Health Group (F.d.M.); data curation, A.T.; original draft preparation, A.T.; review and editing, J.M. and F.d.M.; visualization, A.T.; supervision, F.d.M.; project administration, J.M.; funding acquisition, J.M.

Funding: The study was financially supported by the landscape agency "Landschaftspflegeverband Thüringische Rhön".

Acknowledgments: We thank the stuff of the landscape agency "Landschaftspflegeverband Thüringische Rhön", in particular Gesa Ogan, for their support in this study. We are grateful to Juliane Hahn for valuable suggestions and comments on the laboratory methodology.

Conflicts of Interest: The authors declare no conflicts of interest. The funders had no role in the design of the study, analyses, or interpretation of data; in the writing of the manuscript, or in the decision to publish the results. The funders supported seed sampling.

\section{Appendix A}

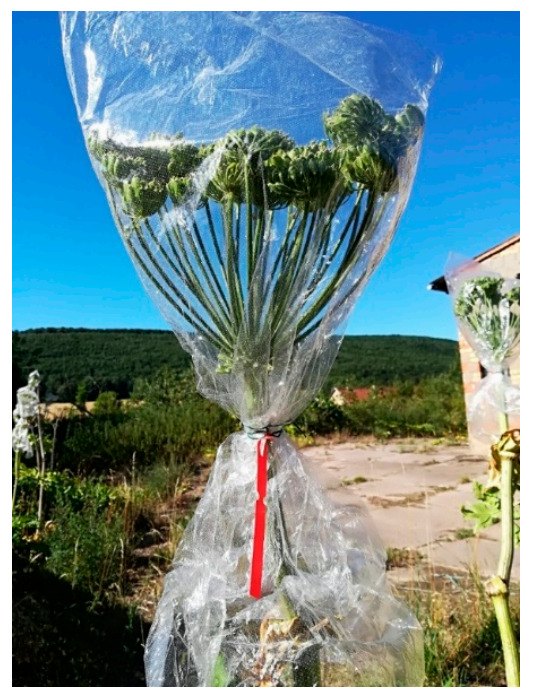

Figure A1. Main Heracleum mantegazzianum umbel wrapped with polyethylene bag.

\section{References}

1. Nielsen, C.; Ravn, H.P.; Nentwig, W.; Wade, M. The Giant Hogweed Best Practice Manual: Guidelines for the Management and Control of An Invasive Weed in Europe; Forest \& Landscape Denmark: Hoersholm, Denmark, 2005; 44p, ISBN 87-7903-211-7.

2. Thiele, J.; Isermann, M.; Kollmann, J.; Otte, A. Impact scores of invasive plants are biased by disregard of environmental co-variation and non-linearity. Neobiota 2011, 10, 65-79. [CrossRef]

3. Braun, M.; Schindler, S.; Essl, F. Distribution and management of invasive alien plant species in protected areas in Central Europe. J. Nat. Conserv. 2016, 33, 48-57. [CrossRef]

4. Hejda, M.; Pyšek, P.; Jarošík, V. Impact of invasive plants on the species richness, diversity and composition of invaded communities. J. Ecol. 2009, 97, 393-403. [CrossRef] 
5. Pyšek, P.; Jarošík, V.; Müllerová, J.; Pergl, J.; Wild, J. Comparing the rate of invasion by Heracleum mantegazzianum at continental, regional, and local scales. Divers. Distrib. 2008, 14, 355-363. [CrossRef]

6. Dalke, I.V.; Chadin, I.F.; Zakhozhiy, I.G.; Malyshev, R.V.; Maslova, S.P.; Tabalenkova, G.N.; Golovko, T.K. Traits of Heracleum sosnowskyi plants in monostand on invaded area. PLoS ONE 2015, 10, e0142833. [CrossRef] [PubMed]

7. Thiele, J.; Otte, A. Invasion patterns of Heracleum mantegazzianum in Germany on the regional and landscape scales. J. Nat. Conserv. 2008, 16, 61-71. [CrossRef]

8. Convention on Biological Diversity; United Nations: New York, NY, USA, 1992; 28 p.

9. Camm, E.; Buck, H.W.L.; Mitchell, J.C. Phytophotodermatitis from Heracleum mantegazzianum. Contact Dermat. 1976, 2, 68-72. [CrossRef]

10. Mack, R.N.; Simberloff, D.; Lonsdale, W.M.; Evans, H.; Clout, M.; Bazzaz, F.A. Biotic invasions: Causes, epidemiology, global consequences, and control. Ecol. Appl. 2000, 10, 689. [CrossRef]

11. Nielsen, C.; Vanaga, I.; Treikale, O.; Priekule, I. Mechanical and Chemical Control of Heracleum mantegazzianum and Heracleum sosnowskyi. In Ecology and Management of Giant Hogweed (Heracleum Mantegazzianum); Pyšek, P., Cock, M.J.W., Nentwig, W., Ravn, H.P., Eds.; CABI: Wallingford, UK; Cambridge, MA, USA, 2007; pp. $226-239$. ISBN 9781845932060.

12. Otte, A.; Eckstein, R.L.; Thiele, J. Heracleum mantegazzianum in its primary distribution range of the Western Greater Caucasus. In Ecology and Management of Giant Hogweed (Heracleum mantegazzianum); Pyšek, P., Cock, M.J.W., Nentwig, W., Ravn, H.P., Eds.; CABI: Wallingford, UK; Cambridge, MA, USA, 2007; pp. $20-41$. ISBN 9781845932060.

13. Jahodová, S.; Fröberg, L.; Pyšek, P.; Geltman, D.; Trybush, S.; Karp, A. Taxonomy, identification, genetic relationships and distribution of large Heracleum species in Europe. In Ecology and Management of Giant Hogweed (Heracleum Mantegazzianum); Pyšek, P., Cock, M.J.W., Nentwig, W., Ravn, H.P., Eds.; CABI: Wallingford, UK; Cambridge, MA, USA, 2007; ISBN 9781845932060.

14. European and Mediterranean Plant Protection Organization. Heracleum mantegazzianum, Heracleum sosnowskyi and Heracleum persicum. EPPO Bull. 2009, 39, 489-499. [CrossRef]

15. Ochsmann, J. Heracleum mantegazzianum SOMMIER \& LEVIER (Apiaceae) in Germany-Studies on biology, distribution, morphology and taxonomy (in German). Feddes Repert. 1996, 107, 557-595. [CrossRef]

16. Tiley, G.E.D.; Dodd, F.S.; Wade, P.M. Heracleum mantegazzianum Sommier \& Levier. J. Ecol. 1996, 84, 297. [CrossRef]

17. Wade, M.; Darby, E.J.; Courtney, A.D.; Caffrey, J.M. Heracleum mantegazzianum: A problem for river managers in the Republic of Ireland and the United Kingdom. In Plant Invasions: Studies from North America and Europe; Brock, J.H., Wade, M., Pyšek, P., Green, D., Eds.; Backhuys Publishers: Leiden, The Netherlands, 1997; pp. 139-151. ISBN 9073348234.

18. Pyšek, P. Heracleum mantegazzianum in the Czech Republic: Dynamics of spreading from the historical perspective. Folia Geobot. Phytotax. 1991, 26, 439-454. [CrossRef]

19. Adolphi, K. Neophytic Cultivated Plants As Crop Refugees of the Rhineland; Berlin, Techn. Univ., Diss.; Galunder: Wiehl, Germany, 1995; ISBN 3931251012. (In German)

20. Page, N.A.; Wall, R.E.; Darbyshire, S.J.; Mulligan, G.A. The Biology of Invasive Alien Plants in Canada. 4. Heracleum mantegazzianum Sommier \& Levier. Can. J. Plant Sci. 2006, 86, 569-589. [CrossRef]

21. Moravcová, L.; Pysek, P.; Krinke, L.; Pergl, J.; Perglová, I.; Thompson, K. Seed germination, dispersal and seed bank in Heracleum mantegazzianum. In Ecology and Management of Giant Hogweed (Heracleum mantegazzianum); Pyšek, P., Cock, M.J.W., Nentwig, W., Ravn, H.P., Eds.; CABI: Wallingford, UK; Cambridge, MA, USA, 2007; pp. 74-91. ISBN 9781845932060.

22. Moravcová, L.; Gudzinskas, Z.; Pysek, P.; Pergl, J.; Perglová, I. Seed ecology of Heracleum mantegazzianum and $H$. sosnowskyi, two invasive species with different distributions in Europe. In Ecology and Management of Giant Hogweed (Heracleum mantegazzianum); Pyšek, P., Cock, M.J.W., Nentwig, W., Ravn, H.P., Eds.; CABI: Wallingford, UK; Cambridge, MA, USA, 2007; pp. 157-169. ISBN 9781845932060.

23. Perglová, I.; Pergl, J.; Pyšek, P. Flowering phenology and reproductive effort of the invasive alien plant Heracleum mantegazzianum. Preslia 2006, 78, 265-285.

24. Perglová, I.; Pergl, J.; Pysek, P. Reproductive ecology of Heracleum mantegazzianum. In Ecology and Management of Giant Hogweed (Heracleum mantegazzianum); Pyšek, P., Cock, M.J.W., Nentwig, W., Ravn, H.P., Eds.; CABI: Wallingford, UK; Cambridge, MA, USA, 2007; pp. 55-73. ISBN 9781845932060. 
25. Moravcová, L.; Pyšek, P.; Pergl, J.; Perglová, I.; Jarošík, V. Seasonal pattern of germination and seed longevity in the invasive species Heracleum mantegazzianum. Preslia 2006, 78, 287-301.

26. Moravcová, L.; Pyšek, P.; Krinke, L.; Müllerová, J.; Perglová, I.; Pergl, J. Long-term survival in soil of seed of the invasive herbaceous plant Heracleum mantegazzianum. Preslia 2018, 90, 225-234. [CrossRef]

27. Pyšek, P. Ecological aspects of invasion by Heracleum mantegazzianum in the Czech Republic. In Ecology and Management of Invasive Riverside Plants; Waal, L.C., Child, L.E., Wade, P.M., Brock, J.H., Eds.; Wiley: Chichester, UK, 1994; pp. 45-54.

28. Vaverková, M.D.; Winkler, J.; Adamcová, D.; Radziemska, M.; Uldrijan, D.; Zloch, J. Municipal solid waste landfill-Vegetation succession in an area transformed by human impact. Ecol. Eng. 2019, 129, 109-114. [CrossRef]

29. Andersen, U.V.; Calov, B. Long-term effects of sheep grazing on giant hogweed (Heracleum mantegazzianum). Hydrobiologia 1996, 340, 277-284. [CrossRef]

30. Lundström, H. Giant hogweed, Heracleum mantegazzianum, a threat to the Swedish countryside. In Proceedings of the Weeds and Weed Control. 25th Swedish Weed Conference, Uppsala, Sweden, February 1984; Volume 1, Reports. pp. 191-200.

31. Jodaugiene, D.; Marcinkeviciene, A.; Sinkeviciene, A. Control of Heracleum sosnowskyi in Lithuania. Julius Kühn Archiv 2018, 458, 275-280. [CrossRef]

32. van Meerbeek, K.; Appels, L.; Dewil, R.; Calmeyn, A.; Lemmens, P.; Muys, B.; Hermy, M. Biomass of invasive plant species as a potential feedstock for bioenergy production. Biofuels Bioprod. Bioref. 2015, 9, $273-282$. [CrossRef]

33. Westerman, P.R.; Gerowitt, B. Weed seed survival during anaerobic digestion in biogas plants. Bot. Rev. 2013, 79, 281-316. [CrossRef]

34. Dahlquist, R.M.; Prather, T.S.; Stapleton, J.J. Time and temperature requirements for weed seed thermal death. Weed Sci. 2007, 55, 619-625. [CrossRef]

35. Hahn, J.; Parzych, D.; Schulz, J.; Westerman, P.R.; Gerowitt, B. Wildflower seeds in the biogas reactor: Screening the risk of survival of different species. Julius Kühn Archiv 2018, 458, 41-46. [CrossRef]

36. Baier, U.; Warthmann, R.; Schleiss, K. Fermentation \& Composting Plants As Hygiene Barriers (in German), Report, 2010, Zürich, 42p. Available online: https://www.biomassesuisse.ch/files/biomasse_temp/data/Das_ bieten_wir/FE_Bericht_Hygienebarrieren_end3.pdf (accessed on 13 May 2019).

37. Hahn, J.; Parzych, D.; Westerman, P.R.; Heiermann, M.; Gerowitt, B. The importance of temperature in the inactivation of seeds in biogas reactors (in German). Julius Kühn Archiv 2016, 452, 123-129. [CrossRef]

38. Moore, R.P. ISTA Handbuch für die Tetrazoliumuntersuchung; 2. Aufl; Internationale Vereinigung für Saatgutprüfung: Zürich, Switzerland, 1985; ISBN 3906549259.

39. Ritz, C.; Streibig, J.C. drc: Analysis of Dose-Response Curves. R Package Version 3.0-1. 2016. Available online: https://CRAN.R-project.org/package=drc (accessed on 18 May 2019).

40. R Core Team. 2019. Available online: http://www.R-project.org/ (accessed on 18 May 2019).

41. Ritz, C.; Baty, F.; Streibig, J.C.; Gerhard, D. Dose-response analysis using R. PLoS ONE 2015, 10, e0146021. [CrossRef]

42. Hothorn, T.; Bretz, F.; Westfall, P. Simultaneus inference in general parametric models. Biom. J. 2008, 50, 346-363. [CrossRef]

43. Hahn, J.; Westerman, P.R.; Heiermann, M.; Gerowitt, B. Survival of seeds from wild-flowering mixtures in the mesophilic, anaerobic digestion of the biogas process. Asp. Appl. Biol. 2015, 131, 187-192.

44. Westerman, P.R.; Hildebrandt, F.; Gerowitt, B. Weed seed survival following ensiling and mesophilic anaerobic digestion in batch reactors. Weed Res. 2012, 52, 286-295. [CrossRef]

45. Westerman, P.R.; Heiermann, M.; Pottberg, U.; Rodemann, B.; Gerowitt, B. Weed seed survival during mesophilic anaerobic digestion in biogas plants. Weed Res. 2012, 52, 307-316. [CrossRef]

46. Egley, G.H. High-temperature effects on germination and survival of weed seeds in soil. Weed Sci. 1990, 38, 429-435. [CrossRef]

47. Eckford, R.E.; Newman, J.C.; Li, X.; Watson, P.R. Thermophilic anaerobic digestion of cattle manure reduces seed viability for four weed species. Int. J. Agric. Biol. Eng. 2012, 5, 71-75.

48. Strauß, G.; Kaplan, T.; Jacobi, T. Germination capability of seeds of different (genetically modified) crop plants depending on process parameters and residence time in a biogas plant (in German). J. Verbr. Lebensm. 2012, 7, 19-25. [CrossRef] 
49. Schrade, S.; Oechsner, H.; Perkun, C.; Claupein, W. Influence of the biogas process on the germination capability of seeds. Landtechnik 2003, 90-91. (In German)

50. Thompson, A.J.; Jones, N.E.; Blair, A.M. The effect of temperature on viability of imbibed weed seeds. Ann. Appl. Biol. 1997, 130, 123-134. [CrossRef]

51. Leonhardt, C.; Weinhappel, M.; Gansberger, M.; Brandstetter, A.; Schally, H.; Pfundtner, E. Investigations on the Risk of Propagation of Seedborne Diseases, Weeds and Sproutable Plant Parts with Fermentation End Products from Biogas Plants: Final Report on the Research Project 100296/2 (in German). Available online: https://www.dafne.at/prod/dafne_plus_common/attachment_download/ 9e9168bbb84a533b517ef792c752ca06/100296_Endbericht_biogas_dafne_letztfassung.pdf (accessed on 18 May 2019).

52. Hay, F.; Probert, R.J. Seed maturity and the effects of different drying conditions on desiccation tolerance and seed longevity in foxglove (Digitalis purpurea L.). Ann. Bot. 1995, 76, 639-647. [CrossRef]

53. Moravcová, L.; Perglová, I.; Pyšek, P.; Jarošík, V.; Pergl, J. Effects of fruit position on fruit mass and seed germination in the alien species Heracleum mantegazzianum (Apiaceae) and the implications for its invasion. Acta Oecol. 2005, 28, 1-10. [CrossRef]

54. Oechsner, H.; Knödler, P.; Gerhards, R. Conditions for the Inactivation of Weed Seeds in the Biogas Process: Biogas Infotage Ulm. Available online: http://docplayer.org/75306345-Bedingungen-zur-inaktivierung-vonunkrautsamen-im-biogasprozess.html (accessed on 18 May 2019).

(C) 2019 by the authors. Licensee MDPI, Basel, Switzerland. This article is an open access article distributed under the terms and conditions of the Creative Commons Attribution (CC BY) license (http://creativecommons.org/licenses/by/4.0/). 